\title{
PENGARUH KEPEMILIKAN MANAJERIAL DAN KEPEMILIKAN INSTITUSIONAL TERHADAP NILAI PERUSAHAAN PADA PERUSAHAAN SEKTOR INDUSTRI BARANG KONSUMSI DI BEI
}

\author{
Friko Allan Kevin Tambalean ${ }^{1}$, Hendrik Manossoh $^{2}$, Treesje Runtu ${ }^{3}$ \\ 1,2,3 Jurusan Akuntansi, Fakultas Ekonomi dan Bisnis, Universitas Sam Ratulangi, Jl. Kampus Bahu, Manado, \\ 95115, Indonesia \\ E-mail : ftambalean@gmail.com
}

\begin{abstract}
The main objective of a business company is to increase the company value shown by the stock price, but the agency conflict can be an obstacle to achieving it. Managerial ownership and institutional ownership are expected to reduce the negative impact of the conflict. This study aims to determine the influence of managerial and institutional ownership on company value. Managerial ownership and institutional ownership measured by percentage of the share ownership of management and institutions in the company. Company value measured by Price to Book Value ratio. This study was conducted by taking a sample of 60 companies in 2016 and 2017. The result of this study shows that managerial ownership do not affect the company value and institutional ownership do not affect the company value.
\end{abstract}

Keywords: Managerial Ownership, Institutional Ownership, Company value

\section{PENDAHULUAN}

Pendirian sebuah perusahaan pasti memiliki tujuan yang ingin dicapai, salah satunya adalah meningkatkan nilai perusahaan. Nilai perusahaan merupakan persepsi para investor terhadap kemampuan suatu entitas bisnis dalam menggunakan dan mengolah segala sumber daya yang dimiliki. Perusahaan yang memiliki kinerja baik tentunya akan menghasilkan nilai perusahaan yang tinggi. Keberhasilan sebuah perusahaan dalam mengelola sumber daya yang dimiliki memberi kesan baik pada investor sehingga menghasilkan peningkatan nilai perusahaan. Salah satu indikator yang menunjukkan nilai suatu perusahaan adalah dengan melihat pada harga sahamnya, tinggi rendahnya harga pasar saham suatu entitas bisnis mencerminkan besarnya nilai perusahaan.

Pemilik perusahaan umumnya membuat suatu perikatan dengan agent yang dianggap lebih berkompeten dalam mengelola aset yang dimiliki dengan asumsi bahwa pihak manajemen lebih memahami kondisi dan medan yang akan dihadapi mampu mengambil tindakan-tindakan yang lebih baik, sehingga dalam hal ini manajer dapat mengambil keputusan strategis yang mampu menghasilkan keuntungan bagi perusahaan yang berdampak pada peningkatan nilai perusahaan serta meningkatkan kesejahteraan principal. Manajemen sebagai pihak yang menggerakkan roda perusahaan memiliki akses terhadap semua informasi mengenai perusahaan sementara pemilik modal hanya memperoleh informasi berdasarkan laporan yang dibuat manajemen. Ketidak seimbangan informasi ini disebut dengan asimetri informasi, hal ini menjadi celah bagi pihak agent untuk melakukan tindakan oportunistik demi kepentingan pribadi dan menyebabkan bertambahnya agency cost. Pemegang saham yang menginginkan peningkatan kesejahteraan lewat modal yang diinvestasikan mengharapkan laba perusahaan yang setinggi-tingginya. Perbedaan kepentingan antara agent dan principal sering disebut sebagai agency conflict. Permasalahan ini dapat menghambat tercapainya peningkatan nilai perusahaan.

Kepemilikan manajerial dan institusional menjadi salah satu solusi dalam menekan dampak negatif dari konflik keagenan. Manageral ownership dapat mensejajarkan 
kepentingan manajemen dan pemilik perusahaan dengan memberi kesempatan pada agent untuk menjadi bagian dari principal sebagai pemegang saham. Institutional ownership dapat menjalankan fungsi pengawasan terhadap kinerja manajemen, pihak institusi biasanya berinvestasi dengan jumlah yang cukup besar sehingga membuat manajemen meningkatkan kinerjanya untuk mencegah modal investor institusi berpindah pada perusahaan lain.

\section{TINJAUAN PUSTAKA}

Teori dan Pengertian Akuntansi. Teori akuntansi adalah suatu rangkaian konsep, definisi, dan dalil yang menyajikan secara sistematis gambaran fenomena akuntansi, serta menjelaskan hubungan antar variabel dalam struktur akuntansi (Hery, 2017: 99). Secara umum, akuntansi dapat diartikan sebagai suatu sistem informasi yang memberikan laporan untuk para pemangku kepentingan dalam perusahaan mengenai aktivitas ekonomi dan kondisi perusahaan (Reeve et al, 2009).

Akuntansi Manajemen. Akuntansi manajemen mengidentifikasi, mengumpulkan, mengukur, mengklasifikasi, dan melaporkan informasi yang bermanfaat bagi pengguna internal dalam merencanakan, mengendalikan, dan mengambil keputusan (Hansen dan Mowen, 2009: 9).

Teori Keagenan. Teori keagenan mendeskripsikan hubungan antara pemegang saham (shareholders) sebagai principal dan manajemen sebagai agen (Ichsan, 2013). Principal bertindak sebagai pemilik perusahaan dan memberikan mandat kepada agent untuk menjalankan entitas bisnis yang dimilikinya sebagai manajemen perusahaan. Perbedaan kepentingan antara manajer dan pemegang saham mengakibatkan timbulnya konfik yang biasa disebut agency conflict (Wiranata dan Nugrahanti, 2013). Asimetri informasi terjadi karena manajer lebih superior dalam menguasai informasi dibanding pihak lain (Manossoh, 2016: 62). Manajer sebagai insider perusahaan mempunyai keunggulan dalam hal informasi dibandingkan dengan pemegang saham yang adalah outsider perusahaan. Manajer dapat memanipulasi keuntungan tersebut melalui pengelolaan informasi yang dilaporkan kepada pemegang saham. Agency cost yang diakibatkan oleh masalah keagenan harus ditanggung oleh perusahaan.

Kepemilikan Manajerial. Kepemilikan manajerial merupakan kondisi di mana manajer memiliki saham perusahaan atau dengan kata lain manajer tersebut sekaligus sebagai pemegang saham perusahaan (Christiawan dan Tarigan, 2007). Managerial ownership dapat mensejajarkan kepentingan agent dan principal sehingga manajemen diharapkan dapat meningkatkan kinerjanya.

Kepemilikan Institusional. Kepemilikan institusional adalah keadaan dimana institusi atau lembaga mempunyai saham pada suatu perusahaan. Keberadaan investor institusional dianggap mampu menjadi mekanisme monitoring yang efektif dalam setiap keputusan yang diambil oleh manajer (Pujiati, 2015). Institutional ownership berperan penting dalam meredam terjadinya konflik keagenan.

Nilai Perusahaan. Nilai perusahaan adalah persepsi masyarakat terhadap pengelolaan sumber daya pada akhir tahun berjalan. Semakin berhasil perusahaan selama beroperasi, semakin tinggi pula persepsi masyarakat yang tercermin pada harga saham perusahaan. Investor menilai dengan bersedia membeli saham perusahaan dengan harga tertentu sesuai dengan persepsi dan keyakinannya. Meningkatnya nilai perusahaan akan meningkatkan kesejahteraan para pemilik yang mana hal ini merupakan keinginan para pemilik perusahaan (Sukirni, 2012). Sudah menjadi tugas dari manajer sebagai agent yang telah diberi mandat oleh para shareholders untuk mengelola perusahaanya. 


\section{METODE PENELITIAN}

Jenis Penelitian. Jenis penelitian ini adalah penelitian kuantitatif dengan menggunakan pendekatan asosiatif yakni penelitian yang bersifat membuktikan adanya hubungan antara dua variabel atau lebih (Sugiyono, 2018: 51).

Tempat dan Waktu Penelitian. Tempat dilaksanakannya penelitian ini adalah Galeri Investasi Bursa Efek Indonesia, yang beralamat di Jalan Kampus Unsrat Bahu, Manado. Penelitian dilakukan pada rentang waktu bulan Agustus 2018 hingga bulan Oktober 2018.

Jenis, Sumber dan Metode Pengumpulan Data. Jenis data yang digunakan dalam penelitian ini adalah data cross section yakni persentase kepemilikan manajerial dan institusional serta nilai perusahaan di akhir tahun yang diperoleh dari laporan keuangan tahunan perusahaan sektor industri barang konsumsi yang listing pada Bursa Efek Indonesia tahun 2016-2017. Menurut sumbernya, penelitian ini menggunakan data sekunder yakni data yang diambil dari sumber penyedia data yang dimaksud. Sumber data yang digunakan oleh peneliti adalah halaman web www.idx.co.id yang merupakan website resmi Bursa Efek Indonesia (BEI). Metode pengumpulan data yang peneliti gunakan dalam penelitian ini adalah dokumentasi, yakni metode untuk mengumpulkan informasi melalui dokumendokumen yang telah tersedia demi menjawab masalah yang ada dalam penelitian. Dalam penelitian ini peneliti memperoleh data yang di arsip dalam www.idx.co.id yang merupakan website resmi Bursa Efek Indonesia (BEI) yakni.

Populasi dan Sampel. Populasi yang diteliti adalah seluruh perusahaan industri sektor barang konsumsi yang terdaftar di Bursa Efek Indonesia pada tahun 2016 sebanyak 37 perusahaan dan tahun 2017 sebanyak 42 perusahaan, jadi total populasi adalah 79 perusahaan. Sampel dari penelitian ini adalah Perusahaan-perusahaan industri sektor barang konsumsi yang terdaftar di bursa efek Indonesia tahun 2016 dan 2017 yang memenuhi kriteria yang ditentukan oleh peneliti.

Metode Sampling. Metode pemilihan sampel yang akan diteliti dalam penelitian ini adalah purposive sampling, yaitu pemilihan sampel yang disengaja atau tidak secara acak. Artinya sampel ditentukan berdasarkan pertimbangan serta karakteristik tertentu yang telah ditentukan oleh peneliti demi memperoleh sampel yang dapat mewakili seluruh populasi. Berdasarkan metode tersebut maka peneliti menentukan terdapat tiga kriteria dalam penentuan sampel penelitian. kriteria yang digunakan dalam pengumpulan sampel adalah sebagai berikut: (1) perusahaan industri barang konsumsi yang listing pada tahun 2016 Bursa Efek Indonesia (BEI); (2) perusahaan industri barang konsumsi yang listing pada tahun 2017 Bursa Efek Indonesia (BEI); dan (3) menyajikan laporan tahunan yang memuat persentase kepemilikan manajerial dan kepemilikan institusional.

\section{Definisi Operasional dan Pengukuran Variabel}

Nilai Perusahaan $(Y)$. Nilai perusahaan adalah nilai jual sebuah perusahaan yang ditunjukkan oleh harga saham perusahaan sebagai cerminan keberhasilan perusahaan dalam mengelola segala sumber daya yang dimilikinya, semakin baik kinerja perusahaan maka semakin tinggi juga harga sahamnya. Instrumen yang digunakan untuk mengukur nilai perusahaan adalah price to book value (PBV). Satuan yang digunakan untuk mengukur PBV adalah persentase $(\%)$ dengan perhitungan sebagai berikut.

$$
\text { PBV }=\text { LOG } \frac{\text { Harga perlembar saham }}{\text { Nilai buku perlembar saham }}
$$

Kepemilikan Manajerial (X1). Kepemilikan manajerial adalah keadaan dimana manajemen mempunyai saham pada perusahaan tempat dia bekerja. Instrumen pengukuran yang digunakan adalah satuan persentase $(\%)$ dengan perhitungan sebagai berikut. 


$$
\text { MANJ }=\frac{\text { Kepemilikan saham manajemen }}{\text { Total jumlah saham perusahaan }} \times 100 \%
$$

Kepemilikan Institusional (X2). Kepemilikan institusional adalah institusi atau lembaga yang mempunyai saham pada suatu perusahaan. Besarnya kepemilikan institusi dapat diukur dengan banyaknya lembar saham perusahaan yang dimiliki oleh pihak institusi. Pengukuran kepemilikan institusional menggunakan satuan persentase (\%) dengan rumus berkut.

$$
\text { INST }=\frac{\text { Kepemilikan saham institusi }}{\text { Total jumlah saham perusahaan }} \times 100 \%
$$

Metode dan Proses Analisis. Regresi linier berganda merupakan alat yang digunakan untuk menganalisis data. Model persamaan yang akan dianalisis dengan metode analisis regresi linear berganda adalah sebagai berikut :

$\begin{array}{ll} & \mathrm{PBV}=\beta 0+\beta 1 \mathrm{MANJ}+\beta 2 \mathrm{INST}+\varepsilon \\ \text { Keterangan : } & \beta 0 \quad: \text { Konstanta } \\ & \text { PBV : Nilai Perusahaan } \\ & \text { MANJ : Kepemilikan Manajerial } \\ & \text { INST }: \text { Kepemilikan Institusional } \\ & \varepsilon \quad: \text { Error term }\end{array}$

Statistik Deskriptif. Analisis statistik deskriptif digunakan untuk memberikan gambaran mengenai variabel-variabel penelitian yang akan diteliti yakni kepemilikan manajerial, kepemilikan institusional, serta nilai perusahaan pada perusahaan sektor industri barang konsumsi di BEI.

Uji Asumsi Klasik. Uji asumsi klasik dilaksanakan supaya model regresi dari metode kuadrat terkecil dapat memberikan penaksir bias linier terbaik agar hasil perhitungan dapat dijelaskan dengan efisien dan akurat. Terdapat 4 uji normalitas yang dilakukan, yakni uji normalitas, multikolinieritas, heteroskedastisitas, dan autokorelasi.

Uji Hipotesis. Uji hipotesis yang digunakan adalah uji t. Fungsi dari uji parsial adalah memperlihatkan besarnya pengaruh tiap-tap variabel independen dalam menjelaskan variasi variabel dependen. Apabila $t$ hitung lebih kecil dari t tabel, maka variabel independen tidak berpengaruh signifikan terhadap variabel dependen, dan sebaliknya.

\section{HASIL PENELITIAN DAN PEMBAHASAN}

\subsection{Hasil Penelitian}

\section{Statistik Deskriptif}

Tabel 1. Descriptive Statistics

\begin{tabular}{ccrrrr}
\hline & N & Minimum & Maximum & \multicolumn{1}{c}{ Mean } & Std. Deviation \\
\hline Kepemilikan Manajerial & 60 & 0,00 & 68,28 & 6,0472 & 13,02415 \\
Kepemilikan Institusional & 60 & 0,00 & 65,49 & 16,3365 & 16,15053 \\
Nilai Perusahaan & 60 & 0,24 & 82,44 & 5,9829 & 13,84145 \\
Valid N (listwise) & 60 & & & & \\
\hline
\end{tabular}

Sumber: Data olahan, 2018

Tabel 1 menunjukkan hasil statistik deskriptif dengan menggunakan aplikasi statistik SPSS 25. Dapat dilihat bahwa kepemilikan manajerial (X1) memiliki nilai minimum sebesar $0,00 \%$ artinya terdapat perusahaan yang tidak memiliki kepemilikan saham oleh pihak manajemen, sedangkan nilai tertinggi berada di angka 68,28\% menandakan terdapat 
perusahaan yang saham mayoritasnya dipegang oleh agen. Tabel 1 di atas juga menunjukkan nilai rata-rata dari kepemilikan manajerial dari 60 perusahaan adalah sebesar 6,0472\%.

Variabel independen yang kedua (X2) yakni kepemilikan institusional, nilai minimumnya adalah $0,00 \%$ sedangkan nilai maksimumnya adalah $65,49 \%$ dan memiliki ratarata di angka 16,3365\%. Ini menunjukkan bahwa dari 60 perusahaan yang menjadi sampel, terdapat perusahaan yang mayoritas pemegang sahamnya adalah pihak institusi, ada juga perusahaan yang sama sekali tidak memiliki pemegang saham dari institusi, dengan rataan kepemilikan institusional berada pada taraf 16,3365\%.

Variabel dependen (Y) yakni nilai perusahaan menunjukan terdapat perusahaan yang memiliki PBV hanya 0,24, yang artinya terdapat perusahaan yang memiliki harga pasar saham berada dibawah nilai buku yang menandakan kinerja yang kurang baik. Nilai tertinggi adalah 82,44 yang menunjukkan bahwa perusahaan tersebut memiliki harga saham jauh melebihi nilai bukunya. Sedangkan untuk rata-rata PBV adalah 59,82 dari sampel berjumlah 60 perusahaan dalam tahun 2016 dan 2017.

\section{Uji Asumsi Klasik}

Uji Normalitas. Hasil uji One-Sample Kolmogorov-Smirnov Test dengan aplikasi statistik SPSS 25 ditunjukkan Tabel 2. Dengan melihat tabel maka dapat disimpulkan bahwa data telah terdistribusi normal karena besarnya nilai Asymp. Sig. (2 tailed) lebih besar dari 0,05.

Tabel 2. One-Sample Kolmogorov-Smirnov Test

\begin{tabular}{|c|c|c|}
\hline \multirow{2}{*}{\multicolumn{2}{|c|}{$\mathrm{N}$}} & Unstandardized Residual \\
\hline & & 60 \\
\hline \multirow[t]{2}{*}{ Normal Parameters ${ }^{\mathrm{a}, \mathrm{b}}$} & Mean & 0,0000000 \\
\hline & Std. Deviation & 0,54072690 \\
\hline \multirow[t]{3}{*}{ Most Extreme Differences } & Absolute & 0,064 \\
\hline & Positive & 0,064 \\
\hline & Negative & $-0,046$ \\
\hline \multirow{2}{*}{\multicolumn{2}{|c|}{$\begin{array}{c}\text { Test Statistic } \\
\text { Asymp. Sig. (2-tailed) }\end{array}$}} & 0,64 \\
\hline & & $0,200^{\mathrm{c}, \mathrm{d}}$ \\
\hline \multicolumn{3}{|c|}{$\begin{array}{l}\text { a. Test distribution is Normal. } \\
\text { b. Calculated from data. } \\
\text { Lilliefors Significance Correction. } \\
\text { is a lower bound of the true significance. }\end{array}$} \\
\hline
\end{tabular}

Sumber: Data olahan, 2018

\section{Uji Multikoliniearitas}

Tabel 3. Coefficients ${ }^{\mathrm{a}}$

\begin{tabular}{|c|c|c|c|c|c|c|c|c|}
\hline \multirow{2}{*}{\multicolumn{2}{|c|}{ Model }} & \multicolumn{2}{|c|}{$\begin{array}{l}\text { Unstandardized } \\
\text { Coefficients }\end{array}$} & \multirow{2}{*}{$\begin{array}{c}\begin{array}{c}\text { Standardized } \\
\text { Coefficients }\end{array} \\
\text { Beta }\end{array}$} & \multirow[t]{2}{*}{$\mathbf{t}$} & \multirow[t]{2}{*}{ Sig. } & \multicolumn{2}{|c|}{$\begin{array}{c}\text { Collinearity } \\
\text { Statistics }\end{array}$} \\
\hline & & B & Std. Error & & & & Tolerance & VIF \\
\hline \multirow{3}{*}{1} & (Constant) & 0,473 & 0,110 & & 9,316 & 0,000 & & \\
\hline & LN_X1 & $-0,006$ & 0,006 & $-0,140$ & $-1,077$ & 0,286 & 0,985 & 1,015 \\
\hline & LN_X2 & $-0,006$ & 0,004 & $-0,181$ & $-1,390$ & 0,170 & 0,985 & 1,015 \\
\hline
\end{tabular}

a. Dependent Variable: $L O G_{-} Y$

Sumber: Data olahan, 2018

Hasil pengolahan data menggunakan SPSS 25 pada Tabel 3 menunjukkan bahwa nilai VIF dari variabel independen kepemilikan manajerial (X1) dan kepemilikan institusional 
(X2) adalah sebesar 1,015. Dasar penentuan terjadi multikolinearitas adalah jika nilai VIF < 0,1 atau nilai VIF > 10 maka terjadi multikolinearitas. Dengan demikian tidak terdapat gejala multikolinearitas dalam penelitian ini.

\section{Uji Heteroskedastisitas}

Tabel 4. Coefficients ${ }^{\mathrm{a}}$

\begin{tabular}{|c|c|c|c|c|c|c|}
\hline & \multirow{2}{*}{ Model } & \multicolumn{2}{|c|}{$\begin{array}{l}\text { Unstandardized } \\
\text { Coefficients }\end{array}$} & \multirow{2}{*}{$\begin{array}{c}\begin{array}{c}\text { Standardized } \\
\text { Coefficients }\end{array} \\
\text { Beta }\end{array}$} & \multirow[t]{2}{*}{$\mathbf{T}$} & \multirow{2}{*}{ Sig. } \\
\hline & & B & Std. Error & & & \\
\hline \multirow[t]{4}{*}{1} & (Constant) & 0,511 & 0,066 & & 7,775 & 0,000 \\
\hline & Kepemilikan Manajerial & $-0,004$ & 0,003 & $-0,140$ & $-1,077$ & 0,286 \\
\hline & Kepemilikan & $-0,004$ & 0,003 & $-0,198$ & $-1,523$ & 0,133 \\
\hline & Institusional & & & & & \\
\hline
\end{tabular}

Sumber: Data olahan, 2018

a. Dependent Variable: RES2

Hasil uji Glejser ditunjukkan pada Tabel 4 Nilai signifikansi variabel independen kepemilikan manajerial dan kepemilikan institusional secara berurutan adalah 0,286 dan 0,133, keduanya lebih besar dari 0,05. Jadi dapat dikatakan bahwa tidak terjadi heteroskedastisitas dalam penelitian ini.

Uji Autokorelasi. Untuk mencari dL dan dU perlu melihat pada tabel Durbin-Watson, dengan jumlah sampel $\mathrm{N}=60$ dan variabel independen berjumlah dua, maka diperoleh nilai dU sebesar 1,6518. Tabel 5 diatas menunjukan nilai Durbin-Watson sebesar 1,869 yang mana lebih besar dari dU dan lebih kecil dari 4-dU. Dengan ini diputuskan bahwa tidak terjadi autokorelasi.

Tabel 5. Model Summary ${ }^{\mathrm{b}}$

\begin{tabular}{crrrrr}
\hline Model & R & R Square & $\begin{array}{c}\text { Adjusted R } \\
\text { Square }\end{array}$ & $\begin{array}{c}\text { Std. Error of } \\
\text { the Estimate }\end{array}$ & Durbin-Watson \\
\hline 1 & $0,215^{\text {a }}$ & 0,046 & 0,013 & 0,55013 & 1,869 \\
\hline
\end{tabular}

a. Predictors: (Constant), Kepemilikan Institusional, Kepemilikan Manajerial

b. Dependent Variable: $L O G \_Y$

Sumber: Data olahan, 2018

Hasil Analisis Regresi Linier Berganda. Berdasarkan hasil uji regresi yang dilakukan dengan menggunakan aplikasi SPSS 25, menunjukkan bahwa nilai konstanta adalah sebesar 0,473, kemudian nilai kepemilikan manajerial (X1) sebesar -0,006 dan kepemilikan institusional (X2) sebesar -0,006 yang semuanya bernilai negatif, yang mana ini menunjukan arah hubungan X1 dan X2 terhadap Y adalah berpengaruh negatif. Tabel 6 di bawah juga menunjukkan bahwa managerial ownership dan institutional ownership memiliki pengaruh negatif terhadap nilai perusahaan, dapat dilihat dari nilai B yang bernilai negatif. Nilai t hitung juga ditunjukkan pada tabel yakni kepemilikan manajerial berujumlah $-1,077$, sedangkan $\mathrm{t}$ hitung kepemilikan institusional sebesar -1,390 dengan signifikansi masingmasing secara berurutan adalah 0,286 dan 0,170. Hasil analisis regresi linier berganda dapat dilihat pada Tabel 6 berikut. 


\begin{tabular}{|c|c|c|c|c|c|c|}
\hline \multicolumn{7}{|c|}{ Tabel 6. Coefficients ${ }^{a}$} \\
\hline & \multirow{3}{*}{ Model } & \multicolumn{2}{|c|}{$\begin{array}{l}\text { Unstandardized } \\
\text { Coefficients }\end{array}$} & $\begin{array}{c}\text { Standardized } \\
\text { Coefficients }\end{array}$ & \multirow{3}{*}{$\mathbf{t}$} & \multirow{3}{*}{ Sig. } \\
\hline & & & Std. & & & \\
\hline & & B & Error & Beta & & \\
\hline \multirow[t]{4}{*}{1} & (Constant) & 0,473 & 0,110 & & 4,306 & 0,000 \\
\hline & Kepemilikan Manajerial & $-0,006$ & 0,006 & $-0,140$ & $-1,077$ & 0,286 \\
\hline & Kepemilikan Institusional & $-0,006$ & 0,004 & $-0,181$ & $-1,390$ & 0,170 \\
\hline & \multicolumn{6}{|c|}{$\begin{array}{l}\text { a. Dependent Variable: } L O G_{-} Y \\
\text { Sumber: Data Olahan, } 2018\end{array}$} \\
\hline
\end{tabular}

Berdasarkan penjelasan dan Tabel 6 di atas, maka diperoleh persamaan regresi sebagai berikut:

$$
\mathrm{PBV}=0,473-0,006 \mathrm{MANJ}-0,006 \mathrm{INST}+\varepsilon
$$

Uji t

\begin{tabular}{|c|c|c|c|c|c|c|}
\hline \multicolumn{7}{|c|}{ Tabel 7. Coefficients ${ }^{\mathrm{a}}$} \\
\hline & \multirow{3}{*}{ Model } & \multicolumn{2}{|c|}{$\begin{array}{l}\text { Unstandardized } \\
\text { Coefficients }\end{array}$} & \multirow[t]{2}{*}{$\begin{array}{l}\text { Standardized } \\
\text { Coefficients }\end{array}$} & \multirow{3}{*}{$\mathbf{t}$} & \multirow{3}{*}{ Sig. } \\
\hline & & & Std. & & & \\
\hline & & B & Error & Beta & & \\
\hline \multirow[t]{3}{*}{1} & (Constant) & 0,473 & 0,110 & & 4,306 & 0,000 \\
\hline & Kepemilikan Manajerial & $-0,006$ & 0,006 & $-0,140$ & $-1,077$ & 0,286 \\
\hline & Kepemilikan Institusional & $-0,006$ & 0,004 & $-0,181$ & $-1,390$ & 0,170 \\
\hline
\end{tabular}

Sumber: Data olahan, 2018

a. Dependent Variable: $L N \_Y$

Uji t dilakukan untuk mengetahui seberapa besar pengaruh satu variabel bebas secara individu dalam menerangkan varian variabel terikat (Priadana dan Muis, 2009). Untuk membuktikan hipotesis tersebut, maka perlu melihat t hitung masing-masing variabel. Cara menentukan apakah variabel bebas berpengaruh signifikan terhadap variabel terikat adalah jika nilai $\mathrm{t}$ hitung $>\mathrm{t}$ tabel. Untuk menentukan letak $\mathrm{t}$ tabel, dilakukan perhitungan dengan rumus $\mathrm{t}$ tabel $=(\alpha / 2 ; \mathrm{n}-\mathrm{k}-1)$ dimana probabilitas atau $\alpha=0,05, \mathrm{n}$ atau jumlah sampel sebanyak 60 , dan $\mathrm{k}$ atau jumlah variabel bebas sebanyak 2 sehingga didapati hasil persamaan $\mathrm{t}$ tabel= $(0,025 ; 57)$.

Uji Hipotesis $\mathrm{H}_{1}=$ Kepemilikan Manajerial Berpengaruh Positif Terhadap Nilai Perusahaan. Berdasarkan hasil output SPSS 25 pada Tabel 7 didapati nilai $t$ hitung kepemilikan manajerial (X1) sebesar 0,755 , untuk menentukan besarnya nilai t tabel maka perlu melihat distribusi nilai t tabel dengan penentuan letak nilai t tabel pada tabel distribusi menggunakan rumus $\mathrm{t}$ tabel $=(0,025 ; 57)$ didapati nilainya adalah 2,002 . Dapat dilihat bahwa t hitung X1 sebesar 1,077 < 2,002, maka dapat diputuskan bahwa managerial ownership tidak berpengaruh signifikan terhadap nilai perusahaan. Dilihat dari signifikansinya $0,286>\alpha=0,05$ menunjukkan juga bahwa kepemilikan manajerial tidak berpengaruh signifikan terhadap variabel terikaat $\mathrm{Y}$ yakni nilai perusahaan, yang artinya $\mathrm{H}_{1}$ ditolak.

Uji Hipotesis $\mathbf{H}_{2}=$ Kepemilikan Institusional Berpengaruh Positif Terhadap Nilai Perusahaan. Pada Tabel 7 dapat dilihat besaran t hitung kepemilikan institusional adalah 1,390. Nilai $\mathrm{t}$ tabel diperoleh dari distribusi nilai t tabel dengan penentuan letak nilai $\mathrm{t}$ tabel pada tabel distribusi menggunakan rumus t tabel $=(0,025 ; 57)$ didapati nilainya adalah 2,002. $\mathrm{t}$ hitung kepemilikan institusional sebesar $1,390<2,002$, dapat ditarik kesimpulan 
bahwa institutional ownership tidak berpengaruh signifikan terhadap nilai perusahaan, dengan signifikansi 0,170 , lebih tinggi dari pada probabilita yakni 0,05 , ini artinya kepemilikan institusional tidak memiliki pengaruh signifikan terhadap variabel terikat $\mathrm{Y}$, maka $\mathrm{H}_{2}$ ditolak.

\subsection{Pembahasan}

Pengaruh Kepemilikan Manajerial terhadap Nilai Perusahaan. Hasil uji hipotesis menunjukan bahwa $\mathrm{H}_{1}$ yakni kepemilkan manajerial berpengaruh positif terhadap nilai perusahaan ditolak. Berdasarkan uji t maka diperoleh hasil bahwa kepemilikan manajerial tidak berpengaruh terhadap nilai perusahaan ditunjukkan dengan nilai $t$ hitung lebih kecil dari nilai t tabel, yang mana sesuai dengan penelitian yang dilakukan oleh Tiastri (2012) yang menyatakan bahwa bahwa kepemilikan manajerial tidak berpengaruh terhadap nilai perusahaan. Managerial ownership dapat menyamakan kepentingan manajer dan pemegang saham, artinya manajer akan merasakan langsung dampak dari keputusan yang diambilnya. Kepemilikan manajerial menjadi instrumen untuk membuat manajemen bekerja dengan lebih optimal karena apabila keputusan yang diambil membuat nilai perusahaan turun, maka manajer yang mempunyai saham akan merasakan kerugian sebagai konsekuensi kepemilikan saham. Tidak berpengaruhnya kepemilikan manajerial terhadap nilai perusahaan diakibatkan oleh jumlah kepemilikan saham oleh pihak manajemen pada perusahaan sektor industri barang konsumsi relatif sangat rendah, sehingga pihak manajemen tidak mendapatkan keuntungan yang diharapkan sebagai salah satu pemilik perusahaan akibat proporsi kepemilikanya yang kecil, dan membuat manajemen tidak meningkatkan kinerjanya seperti yang diharapkan sehingga tidak mempengaruhi nilai perusahaan.

Pengaruh Kepemilikan Institusional terhadap Nilai Perusahaan. Berdasarkan hasil uji t dimana nilai signifikansinya lebih besar dari nilai probabilitas, didapati bahwa kepemilikan institusional tidak berpengaruh signifikan terhadap nilai perusahaan. Dengan ini hipotesis kedua yakni kepemilikan institusional berpengaruh positif terhadap nilai perusahaan ditolak. Hasil ini sesuai dengan hasil penelitian oleh Tiastri (2012) yang menemukan bahwa kepemilikan institusional tidak berpengaruh terhadap nilai perusahaan serta Sari (2016) yang menghasilkan kesimpulan bahwa kepemilikan institusional tidak berpengaruh terhadap nilai perusahaan. Kepemilikan institusional merupakan salah satu instrumen yang dapat mengurangi salah satu hambatan dalam tercapainya peningkatan nilai perusahaan yakni agency conflict. Pihak institusi yang memiliki saham pada perusahaan dapat melakukukan monitoring terhadap kinerja manajer, karena jumlah dana investasi dari pihak institusi biasanya bernilai tinggi sehingga dalam pengambilan keputusan manajer selalu mempertimbangkan dampak yang akan diterima oleh pemilik saham institusi. Hasil penelitian ini menunjukkan bahwa kepemilikan institusional tidak berpengaruh terhadap nilai perusahaan akibat fungsi pengawasan yang diemban oleh kepemilikan institusional tidak memiliki pengaruh yang signifikan dalam mengawasi kinerja manajer. Kurangnya keterlibatan pemilik saham institusi dalam pengambilan keputusan manajer juga mengakibatkan kepemilikan institusional tidak berdampak signifikan terhadap nilai perusahaan.

\section{KESIMPULAN DAN SARAN}

\subsection{Kesimpulan}

Penelitian ini dilaksanakan untuk mengetahui apakah terdapat pengaruh terhadap nilai perusahaan oleh kepemilikan manajerial dan kepemilikan institusional. Berdasarkan hasil analisis data dan hasil output aplikasi statistik SPSS 25, dengan jumlah sampel 60 perusahaan pada tahun 2016 dan 2017 maka dapat ditarik kesimpulan sebagai berikut: 
1. Hasil regresi menunjukkan bahwa kepemilikan manajerial tidak berpengaruh signifikan terhadap nilai perusahaan, diakibatkan jumlah saham yang dimiliki oleh manajemen pada perusahaan sektor industri barang konsumsi tergolong sangat sedikit sehingga manajemen kurang merasakan keuntungan sebagai pemilik perusahaan. Maka hipotesis pertama $\left(\mathrm{H}_{1}\right)$ ditolak.

2. Hasil regresi menunjukkan bahwa institutional ownership tidak berpengaruh signifikan terhadap nilai perusahaan, dikarenakan fungsi monitoring pihak institusi yang memiliki saham pada perusahaan sektor industri barang konsumsi tidak cukup kuat untuk mempengaruhi manajemen dalam mengambil keputusan bisnis, sehingga $\mathrm{H}_{2}$ ditolak.

\subsection{Saran}

Saran yang dapat diberikan oleh peneliti yakni sebagai berikut:

1. Penelitian selanjutnya diharapkan untuk dapat menambah jumlah sampel serta memperluas populasi yang akan diteliti.

2. Penelitian selanjutnya alangkah baiknya menambah rentang waktu data yang akan digunakan untuk diteliti.

3. Penelitian selanjutnya hendaknya menambah jumlah variabel independen yang memiliki kaitan dengan nilai perusahaan.

\section{DAFTAR PUSTAKA}

Christiawan, Yulius Jogi dan Tarigan, Josua. 2007. Kepemilikan Manajerial: Kebijakan Hutang, Kinerja dan Nilai Perusahaan. Jurnal Akuntansi dan Keuangan 9(1):1-8.

Hansen, Don R. dan Mowen, Maryanne M. 2009. Akuntansi Manajerial. Salemba Empat. Jakarta.

Ichsan, Randhy. 2013. Teori Keagenan (Agency Theory). Tanggal Akses: 18 Oktober 2018. http://bungrandhy.wordpress.com/2013/01/12/teori-keagenan-agency-theory

Hery. 2017. Teori Akuntansi, Pendekatan Konsep dan Analisis. PT Grasindo. Jakarta.

Manossoh, Hendrik. 2016. Good Corporate Governance Untuk Meningkatkan Kualitas Laporan Keuangan. PT. Norvile Kharisma Indonesia, Manado.

Pujiati. 2015. Pengaruh Kepemilikan Manajerial, Kepemilikan Institusional, dan Kesempatan Investasi Terhadap Kebijakan Dividen dengan Likuiditas Sebagai Variabel Pemoderasi (Studi Empiris pada Perusahaan Sektor Industri Barang Konsumsi yang Terdaftar di Bursa Efek Indonesia Periode 2008-2013). Skripsi. Universitas Negeri Yogyakarta.

Reeve, james M. et al. 2009. Pengantar Akuntansi. Salemba Empat. Jakarta.

Sari, Novita Liana. 2016. Pengaruh Struktur Kepemilikan Terhadap Nilai Perusahaan Pada Perusahaan Properti Dan Real Estate Yang Terdaftar Di Bei 2010-2014. Skripsi. Fakultas Ekonomi Dan Bisnis Universitas Lampung.

Sugiyono. 2014. Metode Penelitian Kuantitatif, Kualitatif, dan Kombinasi (Mixed Methods). Bandung. Alfabeta.

Sukirni, Dwi. 2012. Kepemilikan Manajerial, Kepemilikan Institusional, Kebijakan Deviden Dan Kebijakan Hutang Analisis Terhadap Nilai Perusahaan. Jurnal Universitas Negeri Semarang 1(2).

Tiastri, Arivina. 2012. Analisis Pengaruh Struktur Kepemilikan, Tingkat Profitabilitas, Dan Keputusan Keuangan Terhadap Nilai Perusahaan (Studi Empiris Pada Perusahaan Manufaktur Yang Terdaftar Di BEI). Fakultas Ekonomi dan Bisnis Universitas Lampung. Bandar Lampung.

Wiranata, Yulius Ardy dan Nugrahanti, Yeterina Widi. 2013. Pengaruh Struktur Kepemilikan Terhadap Profitabilitas Perusahaan Manufaktur di Indonesia. Jurnal Akuntansi dan Keuangan 15(1): 15-26. 